\title{
Cold Atmospheric Helium Plasma Induces Apoptosis by Increasing Intracellular Reactive Oxygen and Nitrogen Species
}

\author{
Latha Ramireddy, ${ }^{\mathrm{a}, *}$ Chih Ho Lai, ${ }^{\mathrm{b}}$ Bih Show Low, ${ }^{\mathrm{c}}$ Chuan Li, ${ }^{\mathrm{d}}$ \\ Jang Hsing Hsieh, a,e Jyh Wei Lee, ${ }^{\mathrm{e}}$ \& Hui Yu Wu ${ }^{\mathrm{b}}$ \\ ${ }^{a}$ Center for Plasma and Thin Film Technologies, Ming Chi University of Technology, Taishan, \\ New Taipei City, Taiwan; 'Department of Microbiology and Immunology, Chang Gung University, \\ Taoyuan, Taiwan; 'Center for General Education, Chang Gung University, Taoyuan, Taiwan; \\ dDepartment of Biomedical Engineering, National Yang Ming University, Taipei, Taiwan; \\ eDepartment of Materials Engineering, Ming Chi University of Technology, Taishan, New Taipei \\ City, Taiwan \\ *Address all correspondence to: Latha Ramireddy, Center for Plasma and Thin Film Technologies, Ming Chi University \\ of Technology, Taishan, New Taipei City, Taiwan; Tel.: +886-2-2908-9899 Ext. 4463; Fax: +886-2-2908-1843, \\ E-mail: latha.ramireddy@gmailcom
}

\begin{abstract}
Cold atmospheric pressure plasma (CAPP) has been proposed as a novel method for anticancer therapy. This field gained much interest in the last decade, with biological applications such as wound healing, bacterial sterilization, and cancer treatment. However, the mechanism at the basis of plasma-cell interaction remains unclear. Here, we studied the effect of helium (He) gas CAPP on oral squamous cell carcinoma (OSCC) in vitro. CAPP treatment was performed under different treatment time conditions: 1, 3, and 5 min. Results showed that CAPP treatment induces cell death in OSCC cells in a dose-dependent manner. He-CAPP also induces cell death and G1 cell cycle arrest associated with the ATM/P53 pathway. Furthermore, CAPP activates the mitochondria-mediated apoptosis pathway by enhancing Bax expression and of the Bcl-2 protein suppression. Hydrogen peroxide $\left(\mathrm{H}_{2} \mathrm{O}_{2}\right)$ generation increased immediately after He plasma treatment but reached basal level after $3 \mathrm{~h}$. Further studies showed that CAPP increases intracellular ROS and RNS and reverts after a long period of plasma treatment. Taken together, these results indicated that He-CAPP induces cell death and cell cycle arrest and activates mitochondria-mediated apoptosis by increasing intracellular reactive oxygen and nitrogen species (ROS and RNS) in OSCC cells. Our study provides deep understanding of He-CAPP's effect on OSCC cells. We suggest that CAPP could be a potential therapeutic and clinical research tool for oral cancer treatment.
\end{abstract}

KEY WORDS: cell culture, cold atmospheric plasma, oral squamous cell carcinoma (OSCC), ROS, RNS

\section{INTRODUCTION}

Plasma is an ionized gas consisting of electrons, ions, neutral atoms, reactive oxygen/ nitrogen species (ROS/RNS), four forms of electromagnetic radiation [infrared, visible, and ultraviolet (UV) light]. ${ }^{1}$ Over the past decade plasma research gained great interest among researchers due to progress in plasma medicine and plasma physics. ${ }^{2}$ Plasma is categorized as thermal (hot) or nonthermal (cold) at near room temperature (less than $40^{\circ}$ ). Cold atmospheric pressure plasma (CAPP) is widely used in many biological and 
medical applications, it is easy to operate and nonhazardous, has high reactive efficiency, and is easy, fast, and cost-efficient. CAPP products can be controlled by adjusting plasma density, composition, and temperature. CAPP has been used for sterilization of medical equipment, ${ }^{3,4}$ wound healing,,${ }^{5-8}$ dental care, ${ }^{9}$ cancer treatment, ${ }^{10-13}$ and other medical applications, wastewater treatment, ${ }^{14}$ food safety management, ${ }^{15}$ and agricultural production. ${ }^{16}$ CAPP has garnered much interest as a cancer treatment option.

Reactive oxygen species are constantly produced in biological systems. It is known that ROS can induce cell growth and proliferation as well as cell death. ${ }^{17}$ Recently plasma-generated free radicals ROS and RNS were identified, including hydroxyl $\left(\mathrm{OH}^{-}\right)$, singlet oxygen $\left({ }^{1} \mathrm{O}_{2}\right)$, ozone $\left(\mathrm{O}_{3}\right)$, superoxide anion $\left(\mathrm{O}_{2}^{-}\right), \mathrm{H}_{2} \mathrm{O}_{2}$ and nitric oxide (NO), and nitrogen dioxide $\left(\mathrm{NO}_{2}\right) \cdot{ }^{18-20}$ Plasma-generated ROS and RNS play dominant roles in anticancer therapy. According to current knowledge, plasma's effects on biological systems are mainly caused by reactive oxygen and nitrogen species (ROS/RNS) via two mechanism: (1) alterations in intracellular redox state and (2) oxidative modifications of proteins involved in signaling pathways. ${ }^{21-23}$ Many studies showed that CAPP induces cell death in various cancer cell lines by promoting ROS generation, mitochondrial dysfunction, DNA damage, and activation of protein pathways. ${ }^{24-26}$ CAPP treatment is a multifaceted process that includes treatment time, voltage, gas composition, and gas flow rate. The most used gases are helium, argon, argon mixed with a small amount of oxygen, water vapor, nitrogen, and air, but other process gases have been used. In this study, we used helium as a feeding gas because it produces a stable, homogenous, and uniform discharge at atmospheric pressure and operates without a dielectric cover over the electrode, yet it is free from filaments, streamers, and arcing. ${ }^{27}$ The aim of this study was to investigate the effect of different plasma treatment times and evaluate the effect of He gas plasma on oral squamous cells.

Oral squamous cell carcinoma (OSCC) is one of the most common head and neck cancer (HNCs), accounting for $\sim 3 \%$ of all cancer cases worldwide. ${ }^{28}$ In general, surgery, radiation, and adjuvant chemoradiation are used to treat early or late stages of OSCC, but the long-term overall survival rate has remained unchanged over the past decade. Novel therapeutic methods are required to treat OSCC to increase long-term survival. CAPP might be one of these. Previous studies revealed that CAPP induces apoptosis by DNA damage, the ataxia telangiectasia mutated (ATM)/P53 signaling pathway, ${ }^{24}$ and epidermal growth factor receptor (EGFR) dysfunction in OSCC. ${ }^{29}$ Many studies have shown that plasma-generated RONS play a role in oxidative damage, activating cell-signaling pathways. It is necessary to understand the CAPP-generated free-radical effect on OSCC. To our knowledge, this is the first study on the CAPP-induced RONS effect on OSCC.

\section{MATERIALS AND METHODS}

\section{A. Reagents and Antibodies}

We used Dulbecco's Modified Eagle medium (DMEM) (Hyclone/GE Healthcare), fetal bovine serum (FBS) (Hyclone), penicillin-streptomycin (Gibco), 3-(4,5-dimethylthiazol- 
2-yl)-2,5-diphenyltetrazolium bromide assay (MTT) (Sigma), 2',7'-dichlorofluorescein diacetate (DCFH-DA) (Cayman Chemical), 4-amino-5-methylamino-29,79-difluorofluorescein diacetate (DAF-FM) (Cayman), and Fluorimetric Hydrogen peroxide kits (Sigma). We used anti-ATM (cell signaling), anti- $\beta$-actin, anti-Bcl-2, anti-Bax (Santa Cruz Biotechnology), anti-Parp, anti-P21 (Protein Tech), anti-P53 (Gene Tex), and horseradish peroxidase- (HRP-) conjugated antirabbit or antimouse IgG antibodies (Santa Cruz).

\section{B. Cell Culture}

Oral squamous cell carcinoma (SCC4) cells were purchased from American Type Culture Collection (ATCC) and cultured in DMEM supplemented with 10\% FBS and $1 \%(\mathrm{v} / \mathrm{v})$ antibiotics (penicillin-streptomycin). The cells were maintained in an incubator at $37^{\circ} \mathrm{C}$ with $5 \% \mathrm{CO}_{2}$ in a humidified condition. Cells were grown to $\sim 90 \%$ confluence for further studies.

\section{CAPP Jet System}

The CAPP jet had a dielectric barrier and quartz tube inner and outer diameters of 2 and $4 \mathrm{~mm}$, respectively. Two electrodes were copper strips (grounded electrode $2.5 \mathrm{~cm}$ and powered electrode $1.5 \mathrm{~cm}$ ) wrapped around the quartz tube. The powered electrode was $2 \mathrm{~mm}$ from the nozzle end and the distance between the grounded and powered electrodes was $1.5 \mathrm{~cm}$. Helium was used as the feeder gas, and the flow rate was controlled using a mass flow controller (MFC). Cold plasma operating parameters are shown in Table 1. The RONS density in the He-CAPP (gas phase) was evaluated using optical emission spectroscopy (OES). ${ }^{30}$

\section{Cell Viability Assay}

Cell viability was measured using MTT assay. Following plasma treatment (for 1-, 3-, and 5-min), the cells $\left(4 \times 10^{5} / 6-\mathrm{cm}\right.$ dish) were incubated for $24 \mathrm{~h} ; 20-\mu \mathrm{L}$ MTT was added into each well and the cells were incubated for $2 \mathrm{~h}$ at $37^{\circ} \mathrm{C}$. The supernatant

TABLE 1: Experimental He-CAPP parameters

\begin{tabular}{|l|c|}
\hline \multicolumn{1}{|c|}{ Parameters } & Value \\
\hline Helium gas flow rate $(\mathrm{slm})$ & 5 \\
\hline Voltage $(\mathrm{kV})$ & 7.5 \\
\hline Frequency $(\mathrm{kHZ})$ & 10 \\
\hline Quartz tube tip to medium surface distance $(\mathrm{cm})$ & 3 \\
\hline Treatment time $(\mathrm{min})$ & $1,3,5$ \\
\hline
\end{tabular}

Volume 10, Issue 4, 2020 
was removed and the formazon crystals were dissolved in isopropanol solution (isopropanol with $0.4 \% 10-\mathrm{N} \mathrm{Hcl}$ ). The absorbance was read at $570 \mathrm{~nm}$ using a microplate spectrophotometer.

\section{E. Cell Cycle Analysis}

The cells $\left(4 \times 10^{5}\right.$ cells $/ 6-\mathrm{cm}$ dish) were seeded and treated with plasma for $1-, 3-$, and 5 -min. Then they were incubated for $24 \mathrm{~h}$ at $37^{\circ} \mathrm{C}$, washed and trypsinized with $1 \%$ trypsinEDTA, and harvested by centrifugation. They were washed twice with phosphate buffered saline (PBS) and then fixed with ice-cold $70 \%$ ethanol and incubated at $40^{\circ} \mathrm{C}$ overnight. After incubation, the cells were collected and washed with PBS, and the pellets were resuspended in $500 \mathrm{uL}$ of propidium iodide (containing Rnase A, $20 \mathrm{ug} / \mathrm{mL}$ and $1 \%$ Triton); then they were incubated in the dark for $30 \mathrm{~min}$ at room temperature. Cell cycles were analyzed using a BD FACSAria instrument (BD Biosciences), calculated from 10,000 cells. The cell cycle percentage was analyzed by Mod Fit LT software (Becton Dickinson).

\section{F. Western Blotting Analysis}

Protein samples were extracted from CAPP-treated cells after $24 \mathrm{~h}$ incubation with RIPA buffer (Bioman Scientific Taiwan) and protease cocktail (G Biosciences). Proteins were quantified using bicinchoninic acid (BCA) assay (Thermo Scientific), then heated for $10 \mathrm{~min}$ at $100^{\circ} \mathrm{C}$ for denaturation. Thirty micrograms of total protein were loaded and separated using $6 \%-12 \%$ sodium dodecyl sulfate polyacrylamide gel electrophoresis (SDS-PAGE), and the molecular size marker (Thermo Scientific) was loaded on each gel to estimate protein molecular weights. The proteins were transferred into Immobilon PVDF membranes (Millipore). The membranes were blocked with 5\% CCS in Trisbuffered saline supplemented with $0.1 \%$ Tween-20 (TBST) at room temperature for 1 h. After blocking, the membranes were rinsed three times in TBST for $10 \mathrm{~min}$ and then incubated with various primary antibodies at $4{ }^{\circ} \mathrm{C}$ overnight. They were washed three times before incubation with secondary antibodies. The secondary antibody horseradish peroxidase was incubated for $1 \mathrm{~h}$ at room temperature. Then the membranes were washed three times with TBST to remove excess antibodies and incubated with ECL Plus reagent (Advansta) and scanned by chemiluminescence (Azure Biosystems, USA).

\section{G. ROS and RNS Detection}

Extracellular ROS $\mathrm{H}_{2} \mathrm{O}_{2}$ levels were determined using a Fluorimetric hydrogen peroxide assay kit (Sigma). Fluorescence intensity was determined at 540/590 nm using a microplate reader according to the manufacturer's protocol. $\mathrm{H}_{2} \mathrm{O}_{2}$ concentration levels were quantified based on an $\mathrm{H}_{2} \mathrm{O}_{2}$ standard curve. Intracellular ROS and NO species were estimated using DCFH-DA and DAF-FM, respectively. To quantitate intracellular ROS and NO levels, after CAPP, the cells were treated with $5 \mathrm{uM}$ of DCFH-DA and $10 \mathrm{uM}$ of DAF-FM diluted in DMEM (serum free) and incubated for $30 \mathrm{~min}$ at 
$37^{\circ} \mathrm{C}$. Fluorescence intensity was measured using the microplate reader at $485 / 535 \mathrm{~nm}$ (DCFH-DA) and at 500/515 nm (DAF-FM).

\section{H. Statistical Analysis}

All experiments were performed in triplicates and the values expressed as mean + SD. Statistical significance was determined using a $t$-test in Microsoft excel; a $p$ value $<0.05$ was considered statistically significant.

\section{RESULTS}

\section{A. He-CAPP Optical Emission Spectra}

The He-CAPP device was designed and assembled in our lab. Figure 1 is a schematic of our experimental setup, which consisted of two electrodes. To ignite the plasma discharges, the applied plasma parameters were as shown in Table 1. To quantify the plasma-generated particles and reactive species, optical emission spectroscopy (OES) was employed for analysis. He-CAPP emission spectra in the 200-900-nm wavelength were captured and are shown in Fig. 2. The $\mathrm{OH}$ radical was identified at a wavelength of $309 \mathrm{~nm}$. Atomic oxygen (O I) at 777 and $844 \mathrm{~nm}$ and excited He at 667, 706, and 728 $\mathrm{nm}$ were observed. Additionally, peaks corresponding to the N2 second positive system

A

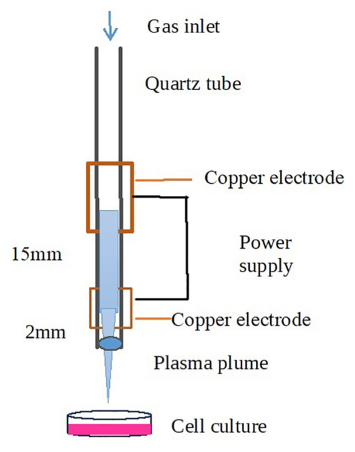

B

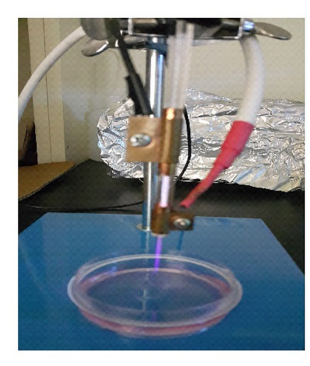

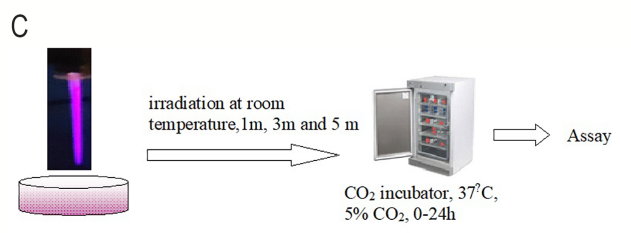

FIG. 1: (A) Schematic of He-CAPP device. (B) Experimental setup and image of plasma jet and induced plasma plume. (C) Schematic of experimental plasma irradiation on oral squamous cells.

Volume 10, Issue 4, 2020 


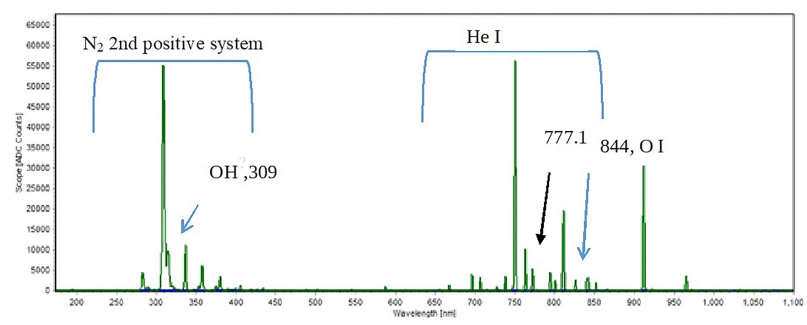

FIG. 2: Optical emission spectrum of He-CAPP (measured at He gas flow rate of $5 \mathrm{slm}, 7.5 \mathrm{kv}$, frequency $10 \mathrm{kHz}$ ), showing major reactive species

at 300-390 nm and the weak N2 first positive system at 610-710 nm were detected (Fig. 2).

\section{B. CAPP Inhibits Cell Growth In Vitro}

To verify the effect of He-CAPP on OSCC cells, we treated cells at 1, 3, and 5 min. After plasma treatment, the cells were incubated for $24 \mathrm{~h}$ and cell viability was assayed using MTT. Control samples were not treated with CAPP but with He only. We included gas-only samples to analyze gas effects on cell viability. The effect of He-CAPP on SCC cells is shown in Fig. 3. Results showed that He-CAPP significantly induced cell death when compared with gas-only controls. He-CAPP effects on cell viability were dose-dependent. Cell viability decreased less than $20 \%$ when compared with controls at the maximal treatment duration of 5 min. However, the He gas-blown samples also showed decreased cell viability when compared with controls but it was statistically nonsignificant.

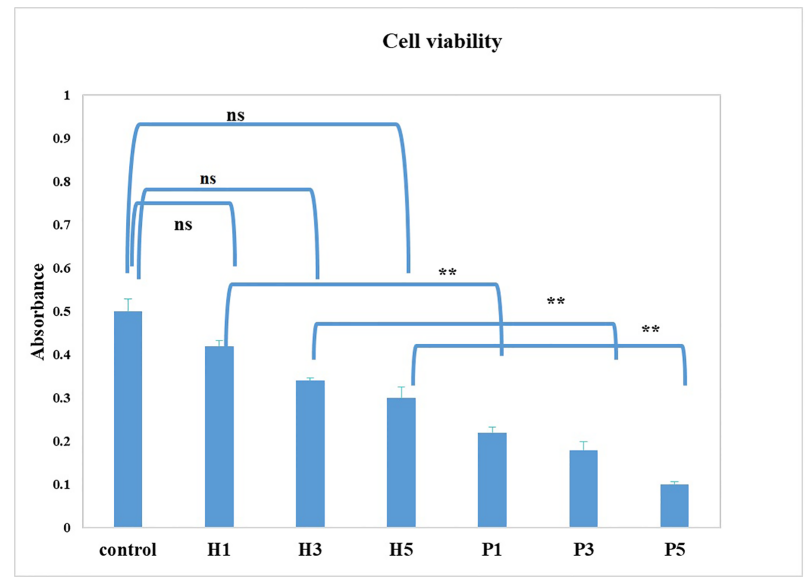

FIG. 3: Effect of He-CAPP on cell viability of SCC 4 cells $24 \mathrm{~h}$ after plasma treatment in irradiation time-dependent manner. ns, non significant; **indicates statistically significant $P \leq 0.05$. 


\section{CAPP-Induced Cell Cycle Arrest}

To know the effect of He-CAPP, we regulated the cell cycle; $24 \mathrm{~h}$ after plasma exposure cells were stained with PI and the cell cycle was analyzed using flow cytometry. For this study cells were treated with He-CAPP for 1, 3, and 5 min; the He gas-blown cells, at 1,3 , and 5 min were included as well as the untreated control samples. Results showed a robust increase in the G1 population at $24 \mathrm{~h}$ after He-CAPP treatment. He-CAPP caused cell cycle arrest in G1, increasing the G1 cell cycle in a dose-dependent manner (Fig. 4A). G2/M cells were decreased $24 \mathrm{~h}$ after He-CAPP treatment. Cells treated with

A
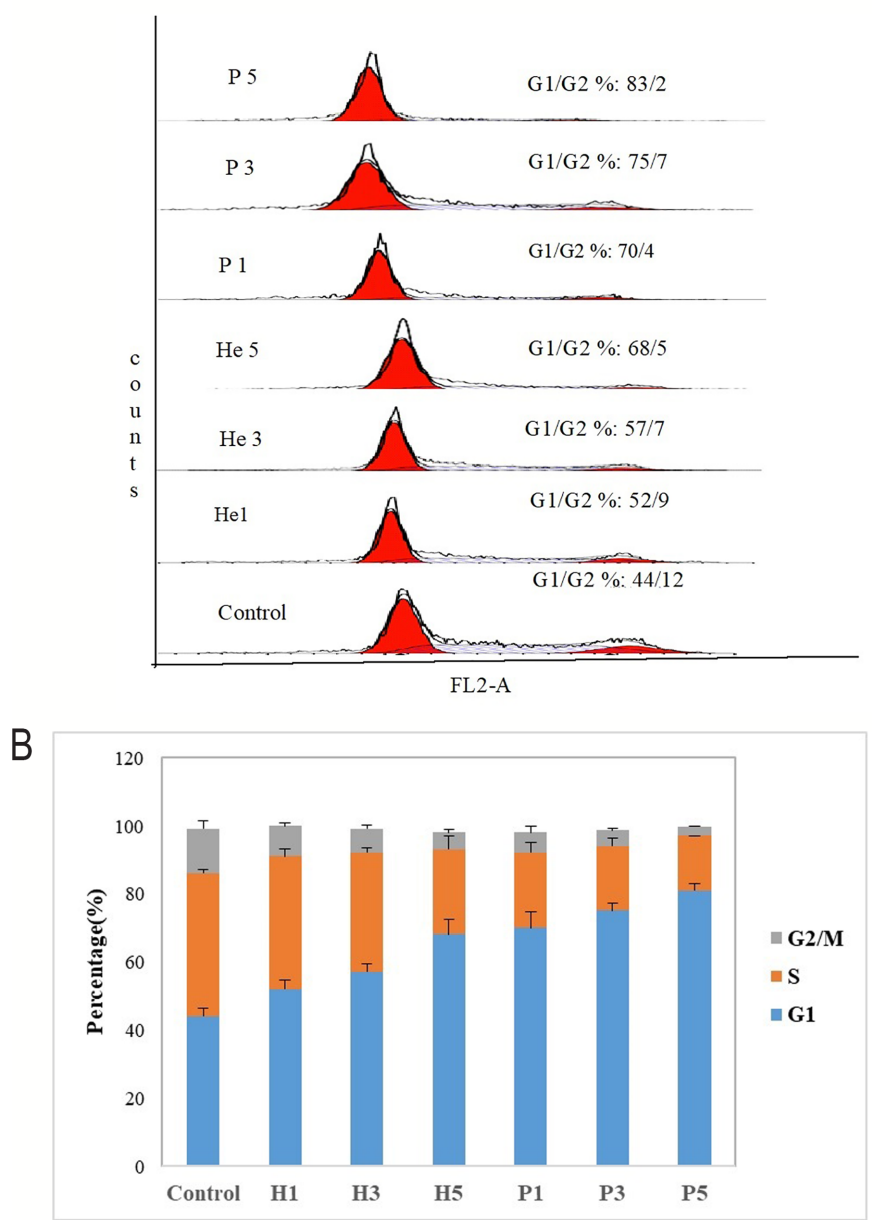

FIG. 4: Cell cycle analysis using flow cytometry by PI staining. (A) G1, S, and G2/M cell cycle phase percentages. (B) Cell cycle phase percentages at various stages. 
He-CAPP for 5 min increased the G1 percentage approximately up to $80 \%$ when compared with controls. The He gas-blown samples showed modest cell cycle increase. Cell cycle percentages are shown in Fig. 4B.

\section{He-CAPP-Induced Cell Death via Apoptotic Pathway}

To elucidate the molecular mechanism of plasma-induced SCC cell apoptosis at $24 \mathrm{~h}$, apoptosis proteins were analyzed. To estimate the effect of He-CAPP on cell death, cells were treated with plasma for 1,3 , and 5 min and control samples were incubated for 24 h. The molecular mechanism of He-CAPP induced the pathways shown in Fig. 5A. To identify the He-CAPP effect on DNA damage and cell cycle arrest, we tested the ATM pathway. The ATM protein was downregulated in plasma-treated samples when compared with controls. He-CAPP induced DNA damage and triggered G1 arrest via the ATM/P53/P21 pathway (Fig. 5B). We also studied whether He-CAPP induced apoptosis through activation of the mitochondria-mediated pathway. Western blot analysis showed that proapoptotic Bax was increased and antiapoptotic Bcl-2 was decreased when compared with controls (Fig. 5B).

\section{E. Extracellular ROS Generation by CAPP Exposure}

We measured plasma-generated ROS in medium with or without cells (Fig. 6A). The supernatant was harvested and the $\mathrm{H}_{2} \mathrm{O}_{2}$ concentration in the supernatant was analyzed by comparison of the $\mathrm{H}_{2} \mathrm{O}_{2}$ standard curve. Immediately after plasma treatment $\mathrm{H}_{2} \mathrm{O}_{2}$ concentration reached approximately $21 \mathrm{uM}$ (5 min plasma-treated) in culture and nonculture medium. $\mathrm{H}_{2} \mathrm{O}_{2}$ concentrations were rapidly decreased after $30 \mathrm{~min}$ and barely identified $3 \mathrm{~h}$ after plasma treatment (Fig. 6B). However, in medium-only (nonculture) supernatant $(5 \mathrm{~min}) \mathrm{H}_{2} \mathrm{O}_{2}$ levels were decreased more slowly until $1 \mathrm{~h}$ when compared with culture medium supernatant. Within $3 \mathrm{~h}, \mathrm{H}_{2} \mathrm{O}_{2}$ reached the same level in culture and nonculture medium supernatants (Fig. 6B).

\section{F. Intracellular ROS and RNS Production in CAPP-Treated OSCC Cells}

To know if He-CAPP induced apoptosis through ROS and RNS generation in OSCC cells, we quantified intracellular ROS and RNS levels using DCFH-DA and DAF-FM. These probes revealed that He-CAPP increased intracellular ROS and RNS in a timedependent manner (Fig. 7). Intracellular RONS were increased at 1 and $3 \mathrm{~h}$ after plasma treatment. Following plasma treatment, intracellular ROS increased twofold when compared with control samples plasma-treated for 5 min (Fig. 7A). Similarly, intracellular RNS were increased at $3 \mathrm{~min}$. Plasma-treated cells increased by approximately 1.7-old in $3 \mathrm{~h}$ following plasma treatment. After $24 \mathrm{~h}$, ROS and RNS reached the same levels as in nontreated controls (Fig. 7B). These data suggest that He-CAPP induces intracellular ROS and RNS. 
A

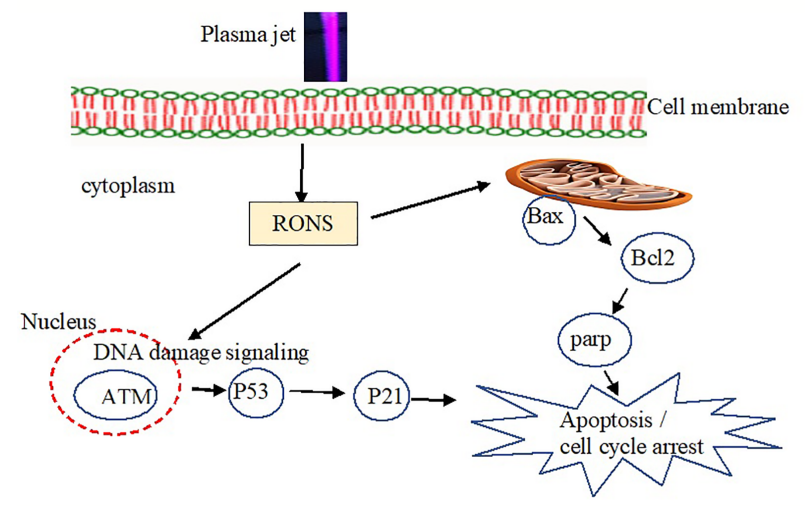

B

CHL H3 HS Pl P3 PS

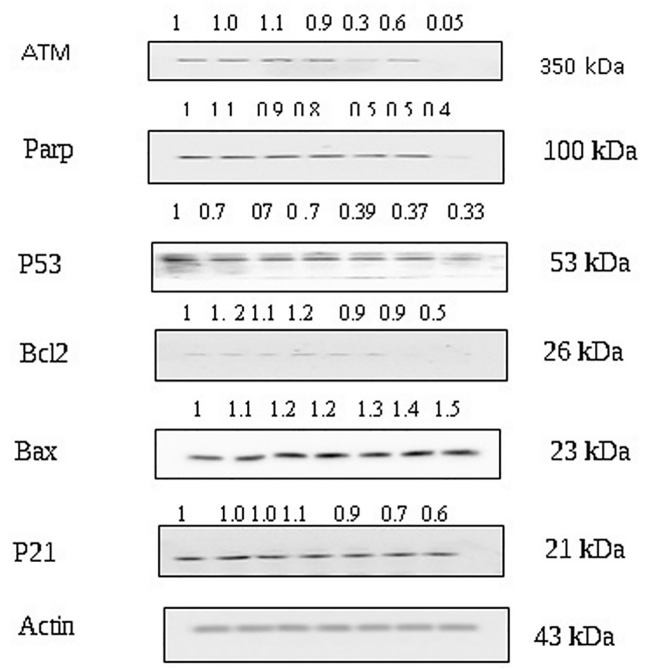

FIG. 5: He-CAPP-induced apoptosis and cell cycle arrest in SCC4 cells. (A) The molecular mechanism of CAPP-induced mitochondrial pathway, ATM/P53/P21 pathway, and mitochondria-mediated pathway in SCC4 cells. (B) Gel-electrophoresed cell lysates $24 \mathrm{~h}$ after He-CAPP treatment. C, control; He1, He3, He5, helium gas flow at 1, 3, and 5 min, respectively; P1, P3, P5, plasma treatment at 1,3, and $5 \mathrm{~min}$, respectively. Three independent experiments with triplicates in each experiment.

\section{DISCUSSION}

CAPP applications are alluring in biomedical fields because of their biologically tolerant temperature. CAPP has been proposed as a novel therapeutic tool for anticancer treatments. Increasing evidence suggest that CAPP selectively induces apoptosis in various

Volume 10, Issue 4, 2020 

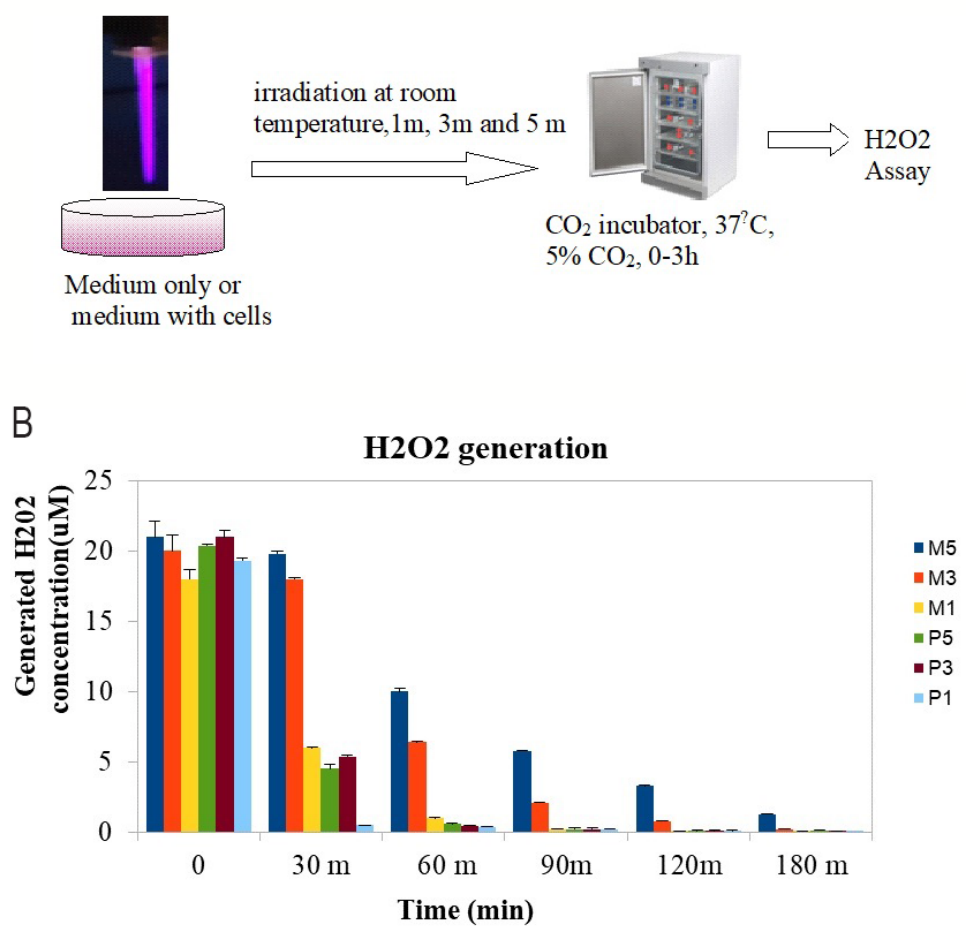

FIG. 6: He-CAPP-induced $\mathrm{H}_{2} \mathrm{O}_{2}$ generation in SCC4 cells. (A) Schematic of experimental procedure for plasma-induced $\mathrm{H}_{2} \mathrm{O}_{2}$. (B) Extracellular $\mathrm{H}_{2} \mathrm{O}_{2}$ concentrations after He-CAPP added to medium-only supernatants and medium with cells.

cancer cell types; the underlying signaling pathways are still unknown. In this study, we found that He-CAPP inhibited cell growth via DNA damage associated with G1 cell cycle arrest and induced the mitochondria-mediated signaling apoptosis pathway via increased RONS generation.

In this study, helium was used as the working gas because it interacts with surrounding air and produces oxygen and nitrogen reactive species. We characterized the reactive species recorded in the emission spectra, which revealed high levels of ROS and RNS (Fig. 2). Therefore, these plasma components, ROS and RNS, have major biological implications. CAPP induces cell death in various cancers including breast, ${ }^{31}$ head and neck, ${ }^{24}$ leukemia, ${ }^{26}$ melanoma, ${ }^{32}$ glioblastoma, ${ }^{33}$ and lung cancers. ${ }^{18}$

We tested the effect of He-CAPP short- and long-term(1, 3, and $5 \mathrm{~min})$ exposure. Results showed that CAPP induced cell death in a dose-dependent manner (Fig. 3). To know the gas effects, helium-only samples were included and results showed a decrease in cell viability. This might be due to either gas flow blow-out or other, unknown, factors. Previous studies showed that gas flow does not induce cell membrane integrity and roughness ${ }^{34}$ and gas- $\left(\mathrm{He}+\mathrm{O}^{-}\right)$only groups treated for $1 \mathrm{~s}$ did not show any significant 

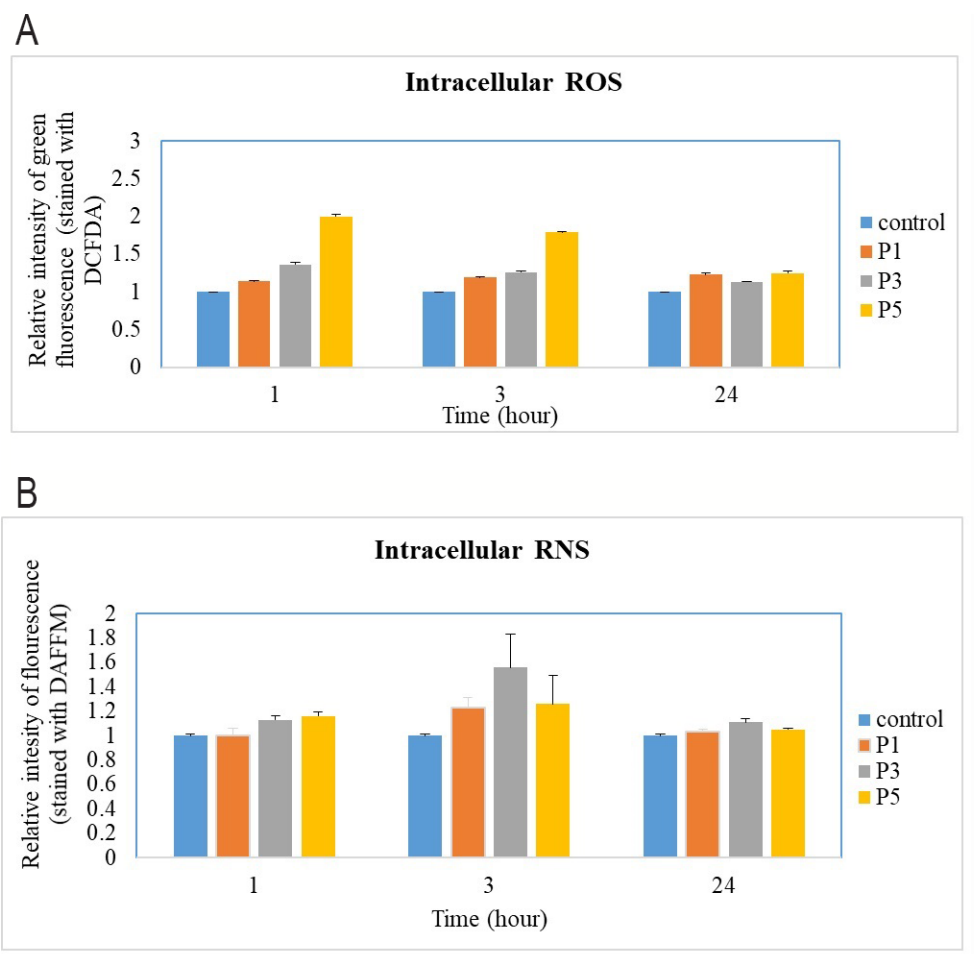

FIG. 7: (A) He-CAPP-induced intracellular ROS levels measured by DCFDA. (B) Intracellular RNS levels measured by DAF-FM.

effect on cell viability. ${ }^{24,35}$ In this study, we also explored the anticancer effect of HeCAPP on OSCs. Cell cycle arrest is a known common response to DNA damage. DNA damage is caused by variety of stimuli to allow damage repair or induction of apoptosis. ${ }^{36}$ After DNA damage, cell cycle arrest is stopped at G1/S or G2/S. ${ }^{37,38}$ Evidence suggests that ATM/P53 plays central role in cell cycle arrest and apoptosis. Therefore, we investigated the He-CAPP effect on the ATM/P53/P21 pathway. ${ }^{39}$ Results showed that He-CAPP induces DNA damage and subsequently triggers the ATM/P53/P21 pathway, which contributes to G1 cell cycle arrest (Fig. 4). Our results, compatible with previous findings, show plasma treatment for $1 \mathrm{~s}$ induces sub-G1cell cycle arrest via the ATM/ p53 pathway. ${ }^{24}$

Apoptosis plays an important role in cancer treatment. Apoptosis includes two major pathways, the death receptor extrinsic pathway and the mitochondria-mediated intrinsic pathway. ${ }^{40,41}$ Previous studies demonstrated that ROS play a major role in the mitochondria apoptotic pathway. The B-cell lymphoma-2 (Bcl-2) family plays a major role in regulation of cell death and survival by controlling mitochondrial permeability. ${ }^{42}$ According to function, the Bcl-2 family is classified as proapoptotic (Bax) and antiapoptotic (Bcl-2) ${ }^{43}$ Previous studies demonstrated that plasma treatment induces mitochondria-mediated apoptosis via ROS generation in HeLa cells. ${ }^{44}$ We also studied the CAPP 
effect on mitochondria-mediated intrinsic apoptosis proteins. Results showed that CAPP increased the expression of proapoptotic Bax protein and decreased antiapoptotic Bcl-2 protein expression. These results demonstrate that CAPP induces apoptosis through the mitochondria-mediated pathway in OSCC cells.

In general, the reactive species are highly reactive and have very short life times. Plasma-generated short-lived reactive species such as the hydroxyl radical, superoxide, singlet oxygen, and nitric oxide were converted into relatively long-lived species such as $\mathrm{H}_{2} \mathrm{O}_{2}$ and nitrite $\left(\mathrm{NO}^{-}\right)$and other species. $\mathrm{H}_{2} \mathrm{O}_{2}$ and $\mathrm{NO}^{-}$are known to induce cell apoptosis and necrosis as well as cell death via DNA double-strand break..$^{45}$ Our results showed that $\mathrm{H}_{2} \mathrm{O}_{2}$ concentration initially increased with plasma treatment and then decreased after $30 \mathrm{~min}$. This more rapid decrease in culture medium than in nonculture medium indicated that cells can promote scavenging of $\mathrm{H}_{2} \mathrm{O}_{2} \cdot{ }^{25}$ We observed liquid-phase $\mathrm{H}_{2} \mathrm{O}_{2}$ involvement in cell death as well as the involvement of other ROS and RNS.

CAPP acts predominantly on cancer cells. It is observed that levels of ROS are higher in cancer cells than in normal cells. CAPP treatment accumulates more ROS, leading to cancer cell death. ${ }^{45}$ Our data reveal that He-CAPP provokes intracellular ROS and RNS generation in OSCC cells. We hypothesize that the increased concentration of plasma reactive species generation comes with increased plasma treatment time. Our results show that He-CAPP may induce cell death with the involvement of mitochondria in apoptosis. Plasma treatment induced intracellular ROS and RNS as reported in previous studies..$^{10,25,46}$

\section{CONCLUSIONS}

Plasma-generated ROS and RNS in the gas phase diffuse into the liquid phase, triggering dynamic chemical reactions and forming a series of aqueous reactive species. Several studies have investigated the connection between plasma-induced RONS generation and plasma-induced apoptosis. ${ }^{47-50}$ However, the time-dependent molecular mechanism of He-CAPP in OSCC has not been studied. We found that treatment with He-CAPP significantly inhibits cell growth in a dose-dependent manner and induces apoptosis via RONS generation in OSCC cells. This induced apoptosis is accompanied by upregulation of Bax and downregulation of Bcl-2. Cell cycle arrest is associated with

the ATM/P53/P21 signaling pathway. Taken together, our results indicate that CAPP is holds promise in human cancer therapy. Additional in vivo and clinical studies are required to know the clinical usefulness of cold plasma.

\section{REFERENCES}

1. Stoffels E, Sakiyama Y, Graves DB. Cold atmospheric plasma: Charged species and their interactions with cells and tissues. IEEE Trans Plasma Sci. 2008;36(4):1441-57.

2. Weltmann KD, von Woedtke T. Plasma medicine — current state of research and medical application. Plasma Physics Controlled Fusion. 2017;59(1):014031. 
3. Heaselgrave W, Shama G, Andrew PW, Kong MG. Inactivation of Acanthamoeba spp. and other ocular pathogens by application of cold atmospheric gas plasma. Appl Environ Microbiol. 2016;82(10):3143-8.

4. Mai-Prochnow A, Murphy AB, McLean KM, Kong MG, Ostrikov KK. Atmospheric pressure plasmas: Infection control and bacterial responses. Int J Antimicrob Agents. 2014;43(6):508-17.

5. Nosenko T, Shimizu T, Morfill GE. Designing plasmas for chronic wound disinfection. New J Physics. 2009;11(11):115013.

6. Daeschlein G, Woedtke TV, Kindel E, Brandenburg R, Weltmann KD, Jünger M. Antibacterial activity of an atmospheric pressure plasma jet against relevant wound pathogens in vitro on a simulated wound environment. Plasma Process Polym. 2010;7: 224-31.

7. Lloyd G, Friedman G, Jafri S, Schultz G, Friedman A, Harding K. Gas plasma: Medical uses and developments in wound care. Plasma Process Polym. 2009;7:194-211.

8. Isbary G, Morfill G, Schmidt HU, Georgi M, Ramrath K, Heinlin J, Karrer S, Landthaler M, Shimizu T, Steffes B, Bunk W, Monetti R, Zimmermann JL, Pimpl R, Stolz W. A first prospective randomized controlled trial to decrease bacterial load using cold atmospheric argon plasma on chronic wounds in patients. Br J Dermatol. 2010;163:78-82.

9. Rupf S, Lehmann A, Hannig M, Schafer B, Schubert A, Feldmann U, Schindler A. Killing of adherent oral microbes by a non-thermal atmospheric plasma jet. J Med Microbiol. 2010;59:206-12.

10. Kong MG, Kroesen G, Morfill G, Nosenko T, Shimizu T, van Dijk J, Zimmermann JL. Plasma medicine: An introductory review. New J Physics. 2009;11(11):115012.

11. Kim JY, Kim SO, Wei YZ, Li JH. A flexible cold microplasma jet using biocompatible dielectric tubes for cancer therapy. Appl Phys Lett. 2010;96:203701.

12. Barekzi N, Laroussi M. Effects of low temperature plasmas on cancer cells. Plasma Process Polym. 2013;10:1039-50.

13. Kolb JF, Mohamed AAH, Price RO, Swanson RJ, Bowman A, Chiavarini RL, Stacey M, Schoenbach KH. Cold atmospheric air plasma jet for medical applications. Appl Phys Lett. 2008; 92:241501.

14. Kim HS, Cho YI, Hwang IH, Lee DH, Cho DJ, Rabinovich A, Fridman A. Use of plasma gliding arc discharges on the inactivation of E. coli in water. Sep Purif Technol. 2013;120:423-8.

15. Scholtz V, Pazlarova J, Souskova H, Khun J, Julak J. Nonthermal plasma - a tool for decontamination and disinfection. Biotechnol Adv. 2015;33:1108-19.

16. Randeniya LK, de Groot GJJB. Non-thermal plasma treatment of agricultural seeds for stimulation of germination, removal of surface contamination and other benefits: A review. Process Polym. 2015;12(7):608-23.

17. Pelicano H, Carney D, Huang P. ROS stress in cancer cells and therapeutic implications. Drug Resist Updat. 2004;7(2):97-110.

18. Adachi T, Tanaka H, Nonomura S, Hara H, Kondo S, Hori M. Plasma-activated medium induces A549 cell injury via a spiral apoptotic cascade involving the mitochondrial-nuclear network. Free Radic Biol Med. 2015;79:28-44.

19. Duprez L, Wirawan E, Berghe TV, Vandenabeele P. Major cell death pathways at a glance. Microbes Infect. 2009;11:1050-62.

20. Xiong S, Mu T, Wang G, Jiang X. Mitochondria-mediated apoptosis in mammals. Protein Cell. 2014;5:737-49.

21. Moldogazieva NT, Mokhosoev IM, Feldman NB, Lutsenko SV. ROS and RNS signalling: Adaptive redox switches through oxidative/nitrosative protein modifications. Free Radic Res. 2018;52(5):507-43.

22. Weiss M, Gumbel D, Hanschmann EM, Mandelkow R, Gelbrich N, Zimmermann U, Walther R, Ekkernkamp A, Sckell A, Kramer A, Burchardt M, Lillig CH, Stope MB. Cold atmospheric plasma treatment induces anti-proliferative effects in prostate cancer cells by redox and apoptotic signaling pathways. PLoS One. 2015;10(7):e0130350.

23. Graves DB. The emerging role of reactive oxygen and nitrogen species in redox biology and

\section{Volume 10, Issue 4, 2020}


some implications for plasma applications to medicine and biology. J Physics D: Appl Physics. 2012;45(26):263001.

24. Chang JW, Kang SU, Shin YS, Kim KI, Seo SJ, Yang SS, Lee JS, Moon E, Baek SJ, Lee K, Kim CH. Non-thermal atmospheric pressure plasma induces apoptosis in oral cavity squamous cell carcinoma: Involvement of DNA-damage-triggering sub-G(1) arrest via the ATM/p53 pathway. Arch Biochem Biophys. 2014;545:133-40.

25. Ahn HJ, Kim KI, Hoan NN, Kim CH, Moon E, Choi KS, Yang SS, Lee JS. Targeting cancer cells with reactive oxygen and nitrogen species generated by atmospheric-pressure air plasma. PLoS One. 2014;9(1):e86173.

26. Barekzi N, Laroussi M. Dose-dependent killing of leukemia cells by low-temperature plasma. J Physics D: Appl Physics. 2012;45(42):422002.

27. Nehra V, Kumar A, Dwivedi HK. Atmospheric non-thermal plasma sources. Int J Eng. 2008;1:53-68.

28. Argiris A, Karamouzis MV, Raben D, Ferris RL. Head and neck cancer. Lancet. 2008;371(9625):1695-709.

29. Lee JH, Om JY, Kim YH, Kim KM, Choi EH, Kim KN. Selective killing effects of cold atmospheric pressure plasma with $\mathrm{NO}$ induced dysfunction of epidermal growth factor receptor in oral squamous cell carcinoma. PLoS One. 2016;11(2):e0150279.

30. Machala Z, Janda M, Hensel K, Jedlovsky I, Lestinka L, Foltin V, Martisovits V, Morvova M. Emission spectroscopy of atmospheric pressure plasmas for biomedical and environmental applications. J Mol Spectrosc. 2007;243:194-201.

31. Wang M, Holmes B, Cheng X, Zhu W, Keidar M, Zhang LG. Cold atmospheric plasma for selectively ablating metastatic breast cancer cells. PLoS One. 2013;8(9):e73741.

32. Ishaq M, Kumar S, Varinli H, Han ZJ, Rider AE, Evans MD, Murphy AB, Ostrikov K. Atmospheric gas plasma-induced ROS production activates TNF-ASK1 pathway for the induction of melanoma cancer cell apoptosis. Mol Biol Cell. 2014;25(9):1523-31.

33. Koritzer J, Boxhammer V, Schafer A, Shimizu T, Klampfl TG, Li YF, Welz C, Zieger SS, Morfill GE, Zimmermann JL, Schelgel J. Restoration of sensitivity in chemo-resistant glioma cells by cold atmospheric plasma. PLoS One. 2013;8(5):e644998.

34. Lunov O, Zablotskii V, Churpita O, Chanova E, Sykova E, Dejneka A, Kubinova S. Cell death induced by ozone and various non-thermal plasmas: Therapeutic perspectives and limitations. Sci Rep. 2014;4:7129.

35. Kang SU, Cho JH, Chang JW, Shin YS, Kim KI, Park JK, Yang SS, Lee JS, Moon E, Lee K, Kim $\mathrm{CH}$. Nonthermal plasma induces head and neck cancer cell death: The potential involvement of mitogen-activated protein kinase-dependent mitochondrial reactive oxygen species. Cell Death Dis. 2014;5:e1056.

36. Cheng Q, Chen J. Mechanism of p53 stabilization by ATM after DNA damage. Cell Cycle. 2010;9:472.

37. Lim D, Jocelyn JM, Yip GW, Bay BH. Silencing the metallothionein-2A gene inhibits cell cycle progression from G1- to S-phase involving ATM and CDC25A signaling in breast cancer cells. Cancer Lett. 2009;276:109-17.

38. Kang J, Ferguson D, Song H, Bassing C, Ckersdorff M, Alt FW, Xu Y. Functional interaction of H2AX, NBS1, and p53 in ATM-dependent DNA damage responses and tumor suppression. Mol Cell Biol. 2005;25:661-70.

39. Bolt J, Vo QN, Kim WJ, McWhorter AJ, Thomson J, Hagensee ME, Friedlander P, Brown KD, Gilbert J. The ATM/p53 pathway is commonly targeted for inactivation in squamous cell carcinoma of the head and neck (SCCHN) by multiple molecular mechanisms. Oral Oncol. 2005;41:1013-20.

40. Lu X, Naidis GV, Laroussi M, Ostrikov K. Guided ionization waves: Theory and experiments. Phys Rep. 2014;540:123-66.

41. Lu X, Naidis GV, Laroussi M, Reuter S, Graves DB, Ostrikov K. Reactive species in non-equilibrium atmospheric-pressure plasmas: Generation, transport, and biological effects. Physics Rep. 2016;630:1-84. 
42. Wang Y, Xiao J, Zhou H, Yang S, Wu X, Jiang C, Zhao Y, Liang D, Li X, Liang G. A novel monocarbonyl analogue of curcumin, (1E,4E)-1,5-Bis(2,3-dimethoxyphenyl)penta-1,4-dien-3-one, induced cancer cell $\mathrm{H} 460$ apoptosis via activation of endoplasmic reticulum stress signaling pathway. J Med Chem. 2011;54:3768-78.

43. Cory S, Adams JM. The Bcl2 family: Regulators of the cellular life-or-death switch. Nat Rev Cancer. 2002;2(9):647-56.

44. Li W, Yu KN, Ma J, Shen J, Cheng C, Zhou F, Zhiming C, Han W. Non-thermal plasma induces mitochondria-mediated apoptotic signaling pathway via ROS generation in HeLa cells. Arch Biochem Biophys. 2017;633:68-77.

45. Kim SJ, Chung TH. Cold atmospheric plasma jet-generated RONS and their selective effects on normal and carcinoma cells. Sci Rep. 2016;6:20332.

46. Yan X, Xiong ZL, Zou F, Zhao SS, Lu X, Yang G, He G, Ostrikov K. Plasma-induced death of HepG2 Cancer Cells: Intracellular effects of reactive species. Plasma Process Polym. 2011;9:59-66.

47. Fridman G, Friedman G, Gutsol A, Shekhter AB, Vasilets VN, Fridman A. Applied plasma medicine. Plasma Process Polym. 2008;5:503-33.

48. Spencer SL, Sorger PK. Measuring and modeling apoptosis in single cells. Cell. 2011;144(6):926-39.

49. Ahn HJ, Kim KI, Kim G, Moon E, Yang SS, Lee JS. Atmospheric-pressure plasma jet induces apoptosis involving mitochondria via generation of free radicals. PLoS One. 2011;6:28154.

50. Zhao S, Xiong Z, Mao X, Meng D, Lei Q, Li Y, Deng P, Chen M, Tu M, Lu X, Yang G, He G. Atmospheric pressure room temperature plasma jets facilitate oxidative and nitrative stress and lead to endoplasmic reticulum stress dependent apoptosis in HepG2 cells. PLoS One. 2013;8:73665.

Volume 10, Issue 4, 2020 
